\title{
Development of Enzyme Activity in the Leydig Cells of the Mouse Testis'
}

\author{
SISTER JEAN WALTER HITZEMAN, O.P.2 \\ Department of Zoology, University of Michigan, \\ Ann Arbor, Michigan
}

In the endocrine portion of the fetal rodent testis, physiological competence is achieved concomitantly with morphological differentiation. Even before the seventeenth day when Leydig cells can be distinguished by PAS staining (RoosenRunge and Anderson, '59), the fetal rat testis has begun to secrete a diffusible androgen-like substance that is capable of stimulating the development of the male genital tract and suppressing ovarian differentiation (Price and Pannabecker, '56; Macintyre, '56). While the hormone has not been identified unequivocally as testosterone (Price, '59), there is cytochemical evidence (Niemi and Ikonen, '61) that 3ß-hydroxysteroid dehydrogenase, an enzyme essential in testosterone synthesis (Samuels et al., '51), is present in the Leydig cells of the fetal rat testis at 15 days.

The initiation of steroidogenesis early in gonadal development presupposes functional metabolic pathways providing energy for synthesis. This survey of enzyme activity and distribution in the developing Leydig cells of the murine testis attempts to define the chronology of androgen production and the metabolic parameters related to it. The mitotic index of these cells is also noted, since the quantification of enzyme activity assumes a knowledge of the growth pattern of the interstitial tissue.

\section{METHODS}

Testes from BALB/c Jax mice were used in all studies. Embryos were considered 12 hours old when vaginal plugs were found, and all ages of fetal animals were determined accordingly. Cytochemical studies were made on testes from fetal mice fourteen and one-half to nineteen and one-half days old, and from animals taken at five-day intervals from zero to 30 days, as well as at 45,60 , and greater than 90 days. Quantitative work included only postpartum mice. Tissues were excised and frozen rapidly in a test tube immersed in an absolute alcohol-dry ice bath at $-65^{\circ} \mathrm{C}$. Sections were cut at $6-10 \mu$ in a cryostat maintained at $-20^{\circ} \mathrm{C}$ and attached to the slides by momentary thawing. Before use, sections were brought to room temperature $\left(23-25^{\circ} \mathrm{C}\right)$ and dried in a current of air. Slides of unfixed sections were placed directly in the incubation medium together with slides holding sections of the same tissue fixed for 20 minutes in: ( 1 ) acetone at $2^{\circ} \mathrm{C}$ (Novikoff et al., '60); (2) acetone at $-65^{\circ} \mathrm{C}$ (Pearson et al., '59); or (3) calciumformol at $4^{\circ} \mathrm{C}$ (Holt, '58). Comparative studies of each enzymatic reaction in the entire age series were based on all four preparations.

Reaction mixtures for the demonstration of oxidative enzymes contained the following final concentrations of reagents: Sørensen phosphate buffer, $27 \mathrm{mM}$, pH 7.4 (exceptions noted below); diphosphopyridine nucleotide (DPN) or triphosphopyridine nucleotide (TPN), $0.66 \mathrm{mM}$ (Sigma; Calif. Corp. Biochem. Res.); nitro blue tetrazolium, $0.14 \mathrm{mM}$ (Nutritional Biochem. Corp.); potassium cyanide, $5 \mathrm{mM}$, and substrate (see below). For diaphorase reactions the substrate was omitted and reduced DPN (DPNH), $0.7 \mathrm{mM}$, or reduced TPN (TPNH), $0.48 \mathrm{mM}$ (Sigma; Calif. Corp. Biochem. Res.) replaced the oxidized nucleotide. For succinic dehydrogenase, sodium succinate, $50 \mathrm{mM}$, and

\footnotetext{
1 Based on a portion of a dissertation submitted in partial fulfillment of the requirements for the degree of Doctor of Philosophy at The University of Michigan, under the direction of Dr. John M. Allen.

2 Present address: Division of Natural Sciences, Siena Heights College, Adrian, Michigan.
} 
phenazine methosulfate, $0.065 \mathrm{mM}$ (Sigma) were used in the same system, without the nucleotide. Final concentrations of substrates and cofactors were: for the DPN-linked lactic or malic dehydrogenases, sodium lactate or sodium L-malate, $50 \mathrm{mM}$ (Nutritional Biochem. Corp.); for 3ß-hydroxysteroid dehydrogenase, dehydroepiandrosterone ( $\Delta^{5}$-androsten-3ß-ol17-one) or related steroids (stock in acetone), $1.0 \mathrm{mM}$ (Sigma); for a-glycerophosphate dehydrogenase, sodium a-glycerophosphate, $30 \mathrm{mM}$ (Eastern) and magnesium sulfate, $20 \mathrm{mM}$; for $\beta$-hydroxybutyric dehydrogenase, $50 \mathrm{mM}$ sodium DL- $\beta$-hydroxybutyrate (Sigma). For TPNlinked isocitric dehydrogenase, $30 \mathrm{mM}$ sodium DL, allo-isocitrate (Sigma) and manganous chloride, $3.8 \mathrm{mM}$, were used. Isocitric dehydrogenase activity was determined at $\mathrm{pH} 7.8$ and 3ß-hydroxysteroid dehydrogenase activity, at $\mathrm{pH}$ 8.0. Sections for DPN-diaphorase visualization were incubated at $37^{\circ} \mathrm{C}$ for eight minutes; otherwise, best results were achieved in 30-40 minutes. During incubation, reaction mixtures were agitated continually by a stream of nitrogen. Controls were incubated in media lacking substrates, coenzymes, or cofactors. Others were subjected to dry heat for one hour at $60^{\circ} \mathrm{C}$ prior to incubation.

Aliesterase was detected by the method of Pearse ('60), using Fast Blue B (diazotized diorthoanisidine, General Dyestuff Company) as the coupling agent. Sections were agitated at room temperature for four-six minutes. Cytochrome oxidase preparations were made following Burstone ('60, '61) and employing either 8amino-1,2,3,4-tetrahydroquinoline, $1.4 \mathrm{mM}$ (Eastman) or 5-hydroxy-1,4-naphthoquinone, $1.2 \mathrm{mM}$ (Aldrich) as couplers. Sections were incubated for 30 minutes at $37^{\circ} \mathrm{C}$. The addition of $5 \mathrm{mg}$ of cytochrome c (Sigma) per $10 \mathrm{ml}$ of medium enhanced the reaction considerably. Cyanide served as an effective control.

Quantitative determinations of enzyme activity were made on tissues homogenized in distilled water at $0^{\circ} \mathrm{C}$, using a TenBrøck all-glass homogenizer. DPN-diaphorase and lactic and malic dehydrogenase activities were assayed at $21^{\circ} \mathrm{C}$ in a
Beckman Model DU spectrophotometer, using Corex cuvettes of $1.0 \mathrm{~cm}$ light path. For diaphorase the reaction mixture contained final concentrations of $30 \mathrm{mM}$ Sørensen phosphate buffer, pH 7.4; $3 \mathrm{mM}$ $\mathrm{KCN} ; 0.03 \mathrm{mM}$ 2,6-dichlorophenol - indophenol (DIP); and $0.33 \mathrm{mM}$ DPNH. Changes in absorbance were measured at 15-second intervals at $600 \mathrm{mu}$, slit width less than $0.01 \mathrm{~mm}$. Results were expressed as moles of dye reduced per minute per $\mathrm{mg}$ of total nitrogen or per $\mathrm{mg}$ of tissue, wet weight. The molar absorbancy index (molar extinction coefficient) of DIP used was $17.8 \times 10^{3} \mathrm{~cm}^{2} / \mathrm{mole}$ (Steyn-Parvé and Beinert, '58). Lactic and malic dehydrogenase activities were assessed by measuring the change in absorbance of DPNH at $340 \mathrm{~m} \mu, 0.04 \mathrm{~mm}$ slit width. Reaction mixtures contained final concentrations of $30 \mathrm{mM}$ Sørensen phosphate buffer, $\mathrm{pH} 7.4 ; 100 \mathrm{mM}$ sodium lactate or sodium L-malate; $3 \mathrm{mM} \mathrm{KCN}$; and $2 \mathrm{mM}$ DPN. Activity was expressed as moles of DPN reduced per minute per $\mathrm{mg}$ of total nitrogen or per $\mathrm{mg}$ of wet weight of tissue, assuming the molar absorbancy index of DPNH as $6.22 \times 10^{6} \mathrm{~cm}^{2} /$ mole (Horecker and Kornberg, '48). Reaction rates were linear over the time measured and determinations were made in duplicate or triplicate against no-substrate and no-coenzyme controls. Reagents for the assay of aliesterase in final concentration were $20 \mathrm{mM}$ Sørensen phosphate buffer, $\mathrm{pH} 7.4$ and 0.3 $\mathrm{mM}$ a-naphthyl acetate (stock in acetone). After incubation at $37^{\circ} \mathrm{C}$, the enzymatically-liberated $\alpha$-naphthol was coupled with Fast Red ITR (diazotized 4-diethylsulfonamido-2-amino-anisole, General Dyestuff Co. ) to yield a colored product, the absorbance of which was recorded at $555 \mathrm{m \mu}$ in a Coleman Model 6A spectrophotometer (Gomori, '53). Results were expressed in moles of a-naphthol liberated per minute per $\mathrm{mg}$ of nitrogen or per $\mathrm{mg}$ of tissue, wet weight. Total nitrogen in the homogenates used for quantitative assays was determined by direct Nesslerization (Levy, '36). The color developed was measured at $460 \mathrm{~m} \mu$ in a Coleman Model 6A spectrophotometer.

Paraffin preparations sectioned at 4-6 $\mu$ and stained with Harris hematoxylin and 
eosin were used for mitotic counts. Ten separate surveys of the number of division figures per hundred Leydig cells were made in 0-day to 45-day testes. Data were analyzed by standard statistical procedures.

\section{CYTOCHEMICAL RESULTS}

Certain strong enzymatic responses of the Leydig cells made it easy to detect their presence in the otherwise unreactive $\mathrm{mu}$ rine testis.

$D P N$-diaphorase activity could be visualized in the interstitial cells at fifteen and one-half days of fetal life (fig. 1). The reaction remained moderate through the first week of neonatal life. After ten days the number of Leydig cells visible in the interstitial areas had been reduced considerably although the responses of individual cells was strong (fig. 2). At 30 days (fig. 3) and thereafter, all the interstices contained Leydig cells which exhibited intense DPN-diaphorase activity.

Lactic and malic dehydrogenase activties were strong between their appearance in the fetal Leydig cells at fifteen and onehalf days and the time of birth (fig. 4). In young postpartum mice the distribution of lactic dehydrogenase was broader than that of malic dehydrogenase. After two weeks, the activity of both catalysts decreased and at 20 days only a few sites of enzyme activity were evident in the sparsely populated interstices. Both enzymes were widely distributed in the Leydig cells after puberty (ca. 28 days), but lactic dehydrogenase responses were more intense.

3ß-hydroxysteroid dehydrogenase was present in the testis of the fifteen and onehalf day mouse embryo, but the reaction was less intense than that of lactic dehydrogenase (fig. 5). During the third week postpartum, the few Leydig cells that could be found were strongly reactive (fig. 6). After 30 days all the interstitial spaces contained reactive cells, but their intensity was diminished noticeably. Gradations of response were sometimes apparent even within a single group of cells (fig. 7). Activity was demonstrated with either pregnenolone ( $\Delta^{5}$-pregnen-3B-ol-20-one) or methylandrostenediol (17-methyl- $\Delta^{5}$-andro- sten-3,17ß-diol) in place of dehydroepiandrosterone as a substrate, but responses were weaker. Leydig cells were unreactive with estradiol $17 \beta$, estrone, and testosterone.

ß-hydroxybutyric dehydrogenase activity was observed in the fetal Leydig cells between sixteen and one-half days and the time of birth. The testis of the newborn mouse contained levels adequate for visualization up to ten days, but after that time no reaction was discerned until puberty. From 30 days on, all Leydig cells showed activity equivalent to that exhibited by 3ß-hydroxysteroid dehydrogenase.

DPN-linked a-glycerophosphate dehydrogenase showed weak reactivity in the interstitial cells of the embryonic testis. This persisted through the first week postpartum. No responses were seen during the interval from 15 to 25 days, but irregular weak reactions were found again after puberty.

Triphosphopyridine nucleotide diaphorase activity was especially prominent in the Leydig cells of the fetal testis from fifteen and one-half days until birth. During late gestation its distribution was quite extensive (fig. 8). In the post-partum animal the TPN-diaphorase reaction became less conspicuous, whereas the moderate DPN-diaphorase levels of the fetal testis were noticeably augmented, and strong responses characterized the Leydig cells after puberty.

Isocitric dehydrogenase was the only TPN-linked enzyme demonstrable in the murine interstitial cells. The enzyme was present beginning at sixteen and one-half days of fetal life. With the exception of the weak responses found during the ten-day interval preceding puberty, the Leydig cells showed levels of isocitric dehydrogenase activity comparable to those of $\beta$-hydroxybutyric dehydrogenase throughout development. A DPN-linked isocitric dehydrogenase occurred only in the seminiferous tubules.

Succinic dehydrogenase activity was particularly difficult to demonstrate adequately in the Leydig cells. Weak, equivocal responses were seen during the first 15 days after birth, and again after 30 days, but no clear picture of enzyme activ- 
ity was found in the fetal testis, or in the interstitial cells during the two weeks preceding puberty.

DPN-linked glutamic dehydrogenase showed such poor, erratic activity even with the addition of magnesium, that attempts to follow it through development were futile. The Leydig cells showed no sorbitol, alcohol, or alanine dehydrogenase activity with DPN as a coenzyme. Neither could 3-phosphoglyceraldehyde dehydrogenase be found, although Himmelhoch and Karnovsky ('61) reported intense activity in rat Leydig cells. There was no evidence of the presence of TPN-linked lactic, malic, $3 \beta$ - or $17 \beta$-hydroxysteroid dehydrogenases.

Aliesterase activity could be ascertained only with difficulty after its appearance in the sixteen and one-half day fetal Leydig cells. The weak responses found in the neonatal testis were almost lost before weaning. Even at 30 days, esterolytic activity, while distributed broadly through the interstices, had not increased greatly in intensity (fig. 9). Within a week, however, esterase levels had risen appreciably, and by 90 days, responses typical of the adult Leydig cells (fig. 10) were obtained.

Cytochrome oxidase was evident in the fetal testis concomitantly with the diaphorases and the associated oxidative enzymes. Like DPN-diaphorase, responses remained moderate during the prepubertal period even when distribution was confined to small aggregates of Leydig cells. Interstitial areas in the adult tissue evinced strong cytochrome oxidase activity.

Phosphatases could not be demonstrated in the murine Leydig cells by these methods: alkaline phosphatase, Gomori (cf. Pearse, ' 60 ), and the modified azo-dye method of Pearse ('60); adenosine triphosphatase, Padykula and Herman ('55) and Wachstein et al. ('60); acid phosphatase, Holt ('59) and Rutenberg and Seligman ('55); and glucose-6-phosphatase, Chiquoine ('55) and Wachstein and Meisel ('57). Only the basement membranes of the tubules and the connective tissue were active, as Baillie ('61) has shown.

\section{QUANTITATIVE RESULTS}

After a small peak of activity at ten days, DPN-diaphorase (table 1) showed a substantial increase between the fifteenth and twentieth days when measured in terms of wet weight of tissue $(P<0.05)$. These data stand in marked contrast to the reduced activity of the other enzymes analyzed during this interval and to supplementary cytochemical evidence. Testicular DPN-diaphorase activity declined sharply after three weeks and levels in the 60-day mouse approximated half of those detected before weaning $(P<0.001)$ when compared on the basis of total nitrogen. In terms of wet weight, the depression was not so drastic. Susequently, a vigorous upsurge brought the diaphorase content of the 90-day testis to its peak activity. During the prepubertal period, lactic dehydrogenase activity declined noticeably (table 1). Based on wet weight, a significant increase $(P<0.025)$ above 25-day levels was attained at 60 days. Malic dehydrogenase levels were depressed after the second week postpartum, and activity remained low thereafter. Aliesterase activity increased between five and ten days according to quantitative data (table 1), but this was not corroborated cytochemically. After a preweaning decline, a sustained rise in esterase activity was observed. Levels at 60 days were significantly greater $(P<0.001)$ than at 25 days when measured on the basis of wet weight.

Extended efforts to assay 3 3 -hydroxysteroid dehydrogenase activity were unavailing, the causes being similar to those indicated elsewhere (Allen, '60). Acetone, ethanol, methanol, and dioxane, which serve as solvents for the steroid substrate, proved as effective as dehydroepiandrosterone itself in supporting the reaction. At highly alkaline $\mathrm{pH}$ values the equilibrium of the reaction is shifted in favor of the product (Talalay, ' 60 ), but the rapid formation of a cyanide-coenzyme complex invalidates absorbancy measurements (Colowick et al., '51). In this $\mathrm{pH}$ range cyanide reacts with acetone also, and interferes with readings (Colowick et al., '51). Substitution of azide for cyanide as a respiratory inhibitor gave inconsistent results. Perhaps there is too little enzyme present to determine activity even under optimum conditions. Homogenates of testes from Bagg albino mice produce 


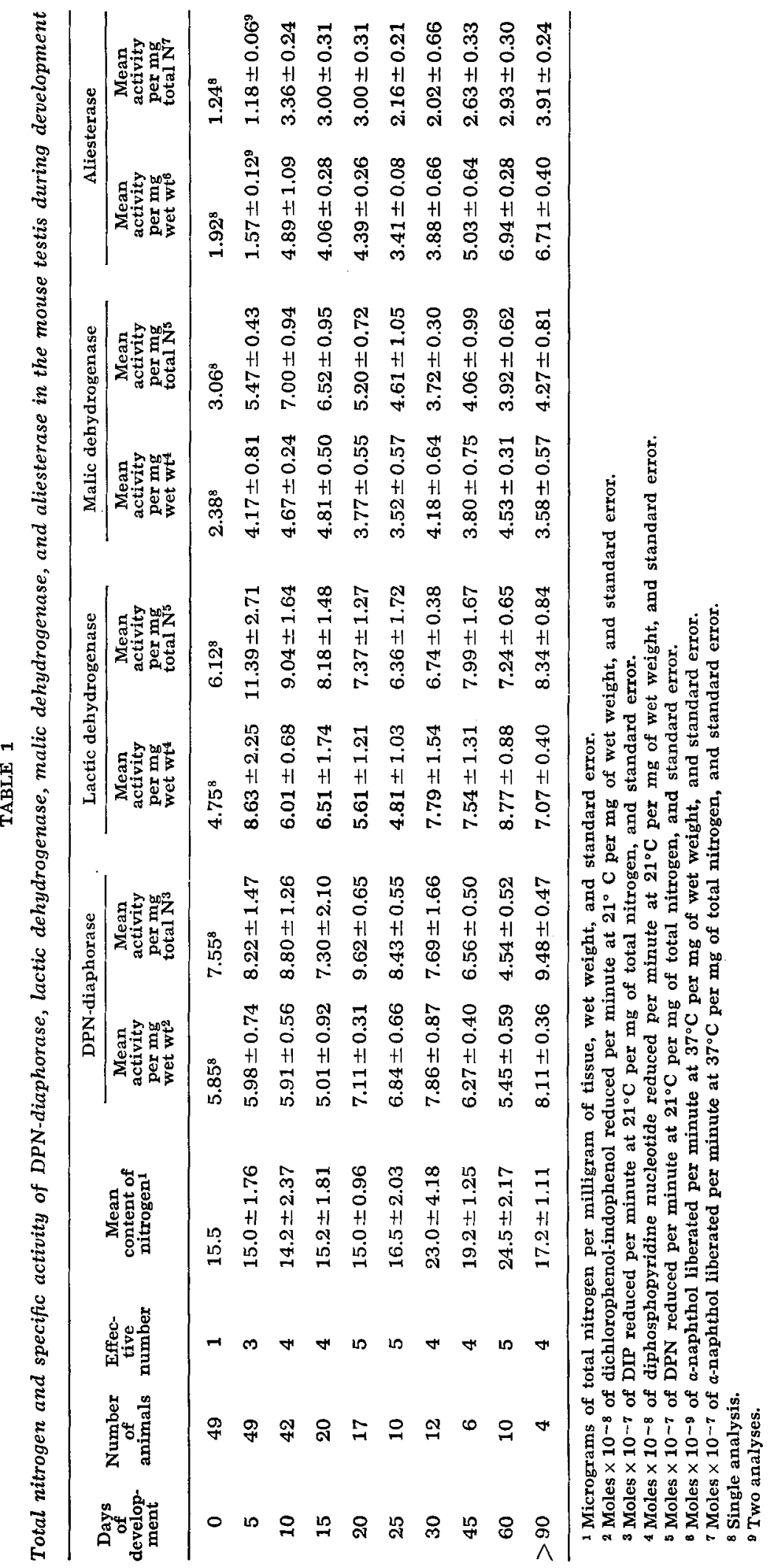


only about 4 umoles of $\alpha, \beta$-unsaturated steroid per gram of tissue per hour of incubation (Huseby et al., '54).

\section{MITOTIC ACTIVITY AND NITROGEN CONTENT}

A marked proliferation of Leydig cells was observed in the differentiating gonad after 16 days of fetal life. Division figures were numerous until the time of birth, when, according to Baillie's calculations ('61), almost three-fourths of the testis consists of intertubular material. Mitotic activity decreased continuously in the neonatal testis (table 2), becoming almost

TABLE 2

Mean mitotic activity in the Leydig cells of the testis of the mouse

\begin{tabular}{ccc}
\hline $\begin{array}{c}\text { Days of } \\
\text { development }\end{array}$ & $\begin{array}{c}\text { Mean } \\
\text { mitotic } \\
\text { activity1 }\end{array}$ & Significance \\
\hline 0 & $13.7 \pm 0.59^{3}$ & $<0.001$ \\
5 & $8.7 \pm 0.91$ & $<0.001$ \\
10 & $3.9 \pm 0.48$ & $<0.001$ \\
15 & $0.5 \pm 0.16$ & $<0.001$ \\
20 & $2.8 \pm 0.52$ & $<0.02$ \\
25 & $1.1 \pm 0.33$ & \\
30 & $1.2 \pm 0.42$ & \\
45 & nihil & \\
\hline
\end{tabular}

1 Percentage of Leydig cells observed in mitosis per 100 cells counted, in ten separate counts, followed by standard error.

2 Probabilities based on the mean differences between successive intervals.

3 Percentage of Leydig cells observed in mitosis pex 100 cells counted, in 20 separate counts, the last ten being made on five different animals after six months.

static at 15 days. Precisely at this time the germinal tissue was beginning to expand rapidly, confining the Leydig cells to progressively smaller interstitial spaces, as Stieve ('23) had noted. They became difficult to identify by conventional morphologic criteria and the nuclei often looked dark and pycnotic. No conclusive statement can be made as to their actual atrophy and disappearance during this period. After 25 days the Leydig cells were more numerous, probably as a result of the slight increase in mitotic activity that preceded weaning. Leydig cell division ceased after the sixth week. Testicular nitrogen remained quite low until the mice became nutritionally independent. Between 20 and 30 days the total nitrogen content increased by $50 \%$ and maximum values were attained by 60 days (table 1 ).

\section{DISCUSSION}

The murine testis separates from the undifferentiated mesenchyme of the genital ridge at eleven and one-half or twelve days of gestation (Brambell, '27). Within four days its endocrine component has undergone sufficient structural differentiation at the subcellular level to support the coordinated activities of DPN- and TPNdiaphorase, cytochrome oxidase, and lactic, malic, isocitric, and $\beta$-hydroxybutyric dehydrogenases. The activity and distribution of these oxidative enzymes suggest that conventional metabolic pathways are present and presumably are competent to furnish energy for hormonal secretion. Visualization of 3ß-hydroxysteroid dehydrogenase from fifteen and one-half days of gestation onward, associated temporally with oxidative activity, implies a degree of biochemical integration requisite for steroidogenesis. The strong mitotic activity found during late gestation marks a growth phase which dominates the gonad at this time. These observations suggest that the murine Leydig cells are biochemically competent for almost a full week before birth and probably capable of fulfilling their secretory function. The increased enzymatic activity of the endocrine tissue through the first week after birth is the result not so much of each Leydig cell producing larger concentrations of a particular catalyst, but of the combined activity of many Leydig cells enhancing the total response.

The variations in intensity of $3 \beta-h y-$ droxysteroid dehydrogenase responses during testicular development suggest that steroid synthesis in the individual Leydig cells is unsynchronized. Conceivably, a relatively small amount of testosterone suffices for normal body needs, once the genital tract becomes functional. If the adrenal cortex produces supplementary androgens (Sommers, '58; Allen, '60), it may, under certain conditions, obviate steroid production by any except a nominal group of Leydig cells. Rubin ('61) has found that the activity of the steroidogenic enzyme may be greater in young rats than in adults, an observation in accord with those made in this study. The activity of 
the enzyme is increased by injections of gonadotropin (Niemi and Ikonen, '62).

The effectiveness of pregnenolone and methylandrostenediol as substrates for the $3 \beta$-hydroxysteroid dehydrogenase reaction implies that this enzyme reacts stereospecifically with the alcohol group in the $3 \beta$ position, oxidizing it to the corresponding ketone (Samuels, '60). Estradiol $17 \beta$ and estrone also have a hydroxyl group in the $\beta$ position on $\mathrm{C}-3$, but the aromatic $A$ ring and loss of the double bond at C-5 alter the conformation so radically that these steroids cannot be accommodated on an enzyme surface adapted to $\Delta^{5}-3 \beta$ molecules. Positive results with the substrates used allow no conclusion as to the major pathway of testosterone synthesis. The Leydig cells of the mouse testis may utilize the conventional pathway through pregnenolone and progesterone to androstenedione ( $\Delta^{4}$-androsten-3,17-dione) (Slaunwhite and Samuels, '56), or they may synthesize the steroid by way of 17-hydroxypregnenolone and dehydroepiandrosterone, an alternate pathway used by the adrenal cortex (Goldstein et al., '60). In both routes the $3 \beta$ hydroxysteroid enzyme is essential. Methylandrostenediol can be converted to methyltestosterone, but it is not a normal substrate for the $3 \beta$ enzyme in mammalian tissue.

The slow accumulation of esterase before puberty suggests that the synthesis of this enzyme may be stimulated by rising hormone levels. Esterolytic responses are prominent in the corpus luteum of the rat ovary (Hunter and Kneiske, '57) and Allen ('58) has suggested that ovarian hormones may be responsible for the high aliesterase levels in the adrenal cortex of the adult female mouse. In the interstitial cells of the rat, low prepubertal esterase levels are doubled between days 27 and 29 , and adult concentrations are attained during the following week. Huggins and Moulton ('48) have correlated these data with androgen production and pituitary gonadotropins. In the rat liver, aliesterase rises slowly to a maximum at six weeks (Flint et al., '60). The striking association of high nonspecific esterase activity in the mature adrenal, ovarian, testicular, and liver tissues, all of which produce steroids, suggests that esterase may be related in some obscure manner to steroid synthesis.

There are few cytochemical techniques available which yield direct information on glycolytic pathways. Since glyceraldehyde-3-phosphate dehydrogenase was not found, and both the a-glycerophosphate and lactic dehydrogenases visualized in this survey are only peripheral enzymes defining possible shunts in the direct route from glucose to pyruvic acid, it is impossible to determine the operational status of the Embden-Meyerhof pathway in the murine Leydig cells. The strong and widelydistributed activity of TPN-diaphorase would be anticipated if the interstitial cells were deriving their energy by means of the hexose monophosphate pathway which generates TPNH. This pathway has been demonstrated in mammalian testes (Field et al., '60). As for the key TPN-linked enzymes in this shunt, glucose6-phosphate dehydrogenase could not be visualized in the murine testis, and a reliable method for demonstrating 6-phosphogluconate dehydrogenase is lacking. Niemi and Ikonen ('62), however, have demonstrated glucose-6-phosphate dehydrogenase activity in the Leydig cells of the rat. The TPNH produced by this glycolytic pathway could be reoxidized in the process of steroid synthesis. Lynn and Brown ('58) have shown that the testicular oxidative enzymes responsible for converting progesterone to testosterone require TPNH in stoichiometric amounts. The elimination of part of the accumulating TPNH by a steroidogenic system would do away with the need for large amounts of TPN-diaphorase. It is possible that increased androgen production is correlated with the decrease in TPN-diaphorase seen in the mouse testis shortly after birth.

Hormonal precursors exercise reciprocal control over the hexose monophosphate shunt and consequently over the amount of TPNH it produces. Catalytic concentrations of testosterone intermediates inhibit glucose-6-phosphate dehydrogenase, thereby decreasing the rate of glycolysis and TPNH formation (McKerns and Kaleita, '60). If such mutual regulatory mechanisms are functional in the murine Leydig cells, the triggering of the Embden- 
Meyerhof pathway would be obligatory only when excessive steroid precursors blocked the hexose monophosphate shunt.

Quantitative determinations of lactic and malic dehydrogenases and aliesterase activities support cytochemical observations. The prepubertal reduction of specific dehydrogenases, apparent cytochemically and quantitatively, is not a consequence of depleted DPN-diaphorase levels (Cascarano and Zweifach, '59), since these increase between 15 and 20 days. Although quantitatives studies showed DPNdiaphorase diminution after day 20 , the activity of this enzyme was not depressed according to cytochemical criteria. The tremendous increase in the germinal tissue evidenced by elevated levels of total nitrogen and the general histological picture, may have acted to dilute the diaphorase content of the homogenate.

Within the time course of maturation, patterns of enzymatic responses may bear the imprint of major developmental crises without necessarily being causally linked to them. Thus, substantial increases in enzyme activity precede birth (Dawkins, '61) and weaning (Moog, '51). Fluctuations in oxidative enzyme levels within the testicular interstitium are a meaningful expression of the growth pattern of a composite organ. The steady increase in enzyme responses in the fetal Leydig cells continues unabated through the first week of postnatal life and reflects clearly the initial activity of the endocrine tissue. But as the germinal epithelium inaugurates a second testicular growth phase during the third week after birth, the wave of Leydig cell division subsides and enzyme responses associated with these cells decline correspondingly. In the postpubertal animal the two cycles are gradually synchronized. Augmented catalytic activity brings the assemblage of demonstrable interstitial enzymes to adult levels soon after reproductive maturity.

\section{SUMMARY}

The Leydig cells of the mouse testis display partial physiological differentiation after the fifteenth day of gestation, as indicated by the presence of DPN- and TPNdiaphorase, malic, lactic, $\beta$-hydroxybutyric, and isocitric dehydrogenases, and cytochrome oxidase. Early androgen synthesis is postulated on the basis of cytochemical evidence for 3ß-hydroxysteroid dehydrogenase at this time. The DPN-linked $\alpha$ glycerophosphate dehydrogenase appears a few days before birth, but succinic dehydrogenase is first seen in the neonatal testis, and aliesterase becomes intense only after 30 days.

A marked depression of most of the DPN-linked catalysts, DPN-diaphorase excepted, occurs between the fifteenth and the twenty-fifth day postpartum. This decline in enzymatic activity is correlated with initiation of growth in the seminal epithelium and the dearth of Leydig cells in the interstices, following a sharp decrease in mitosis during the first week after birth. All enzymes achieve maximum distribution after puberty. DPNdiaphorase undergoes a significant decline in activity extending beyond the beginning of reproductive maturity. Levels are restored to their former peak at 90 days. Enzymatic fluctuations in the Leydig cells reveal one phase of the developmental pattern of the testis. A reciprocal control scheme between glycolytic pathways and steroidogenesis is considered.

\section{LITERATURE CITED}

Allen, J. 1958 A chemical and histochemical study of aliesterase in the adrenal gland of the developing mouse. Anat. Rec., 132: 195-208. 1960 A histochemical study of $3 \beta$-sterol dehydrogenase in the adrenal cortex of the developing mouse. Ibid., 137: 57-63.

Baillie, A. 1961 Observations on the growth and histochemistry of the Leydig tissue in the postnatal prepubertal mouse testis. J. Anat., 95: $357-370$.

Brambell, F. 1927 The development and morphology of the gonad of the mouse. Proc. Roy. Soc., B., 101: 391-409.

Cascarano, J., and B. Zweifach 1959 Factors influencing the histochemical demonstration of coenzyme-dependent dehydrogenases and diaphorases. J. Biophys Biochem. Cytol., 5: 309318.

Chiquoine, A. 1955 Further studies on the histochemistry of glucose-6-phosphatase. J. Histochem. Cytochem., 3: 471-478.

Colowick, S., N. Kaplan and M. Ciotti 1951 The reaction of pyridine nucleotide with cyanide and its analytical use. J. Biol. Chem., 191: $447-459$.

Dawkins, M. 1961 Changes in glucose-6-phosphatase activity in liver and kidney at birth. Nature, 191: 72-73. 
Field, J., I. Pastan, B. Herring and P. Johnson 1960 Studies on pathways of glucose metabolism of endocrine tissues. Endocrin., 67: 801-806.

Flint, M., G. Lathe, T. Ricketts and G. Silman 1960 Changes in microsomal enzyme systems in the liver of newborn rabbits. Biochem. J., 75: 10P.

Goldstein, M., M. Gut and R. Dorfman 1960 Conversion of pregnenolone to dehydroepiandrosterone. Biochim. Biophys. Acta, 38: 190-191.

Gomori, G. 1953 Human esterases. J. Lab. Clin. Med., 42: 445-453.

Himmelhoch, S., and M. Karnovsky 1961 The histochemical demonstration of glyceraldehyde3-phosphate dehydrogenase activity. J. Biophys. Biochem. Cytol., 9: 573-581.

Holt, S. 1959 Factors governing the validity of staining methods for enzymes, and their bearing upon the Gomori acid phosphatase technique. Exptl. Cell Res., Suppl, 7: 1-27.

Horecker, B., and A. Kornberg 1948 The extinction coefficients of the reduced band of pyridine nucleotides. J. Biol. Chem., 175: 385390.

Huggins, C., and S. Moulton 1948 Esterase of testis and other tissues. J. Exptl. Med., 88: 169-179.

Hunter, R., and K. Kneiske 1957 Quantitative study of non-specific esterase in the rat ovary. J. Histochem. Cytochem., 5: 154-158.

Huseby, R., L. Samuels and M. Helmreich 1954 Steroid-3 $\beta$-ol dehydrogenase activity and androgen production in adrenal and interstitial-cell tumors of mice. Proc. Soc. Exptl. Biol. Med., 86: $580-586$.

Levy, M. 1936 Studies on enzymatic histochemistry. XVII. A micro-Kjeldahl estimation. C. R. Trav. Carlsberg, Sér. Chim., 21: 101-110.

Lynn, W., and R. Brown 1958 The conversion of progesterone to androgens by testes. J. Biol. Chem., 232: 1015-1030.

Macintyre, M. 1956 Effect of testes on ovarian differentiation in heterosexual embryonic rat gonad transplants. Anat. Rec., 124: 27-45.

McKerns, K., and E. Kaleita 1960 Inhibition of glucose-6-phosphate dehydrogenase by hormones. Biochem. Biophys. Res. Comm., 2: 344-348.

Moog, F. 1951 The functional differentiation of the small intestine. II. The differentiation of alkaline phosphomonoesterase in the duodenum of the mouse. J. Exp. Zool., 118: 187207.


dehydrogenase activity in foetal Leydig's cells. Nature, 189: 592-593.

- 1962 Cytochemistry of oxidative enzyme systems in the Leydig cells of the rat testis and their functional significance. Endocrin., 70: 167-174.
Padykula, H., and E. Herman 1955 Factors affecting the activity of adenosine triphosphatase and other phosphatases as measured by histochemical techniques. J. Histochem. Cytochem., 3: 161-169.

Pearse, A. 1960 Histochemistry, Theoretical and Applied. Second ed. Little, Brown, and Company, Boston.

Price, D. 1959 In: Endocrines in Development. R. Watterson, ed. University of Chicago Press, Chicago, pp. 33-37.

Price, D., and R. Pannabecker 1956 Organ culture studies. of foetal rat reproductive tracts. Ciba Found. Colloq. on Ageing, 2: 3-17.

Roosen-Runge, E., and D. Anderson 1959 The development of the interstitial cells in the testis of the albino rat. Acta Anat., 37: 125137.

Rubin, B. 1961 In discussion following Huseby, R., O. Dominquez, and L. Samuels 1961 Function of normal and abnormal testicular interstitial cells in the mouse. Rec. Prog. Horm. Res., 17: 1-51.

Rutenburg, A., and A. Seligman 1955 The histochemical demonstration of acid phosphatase by a post-incubation coupling technique. J. Histochem. Cytochem., 3: 455-470.

Samuels, L. 1960 Metabolism of steroid hormones. In: Metabolic Pathways. D. Greenberg, ed. Academic Press, New York, pp. 431480 .

Samuels, L., M. Helmreich, M. Lasater and H. Reich 1951 An enzyme in endocrine tissues which oxidizes $\Delta^{5}-3 \beta$ hydroxy steroids to $a, \beta$ unsaturated ketones. Science, 113: 490-491.

Slaunwhite, W., and L. Samuels 1956 Progesterone as a precursor of testicular androgens. J. Biol. Chem., 220: 341-352.

Sommers, S. 1958 The pituitary and hypothalamus. In: The Endocrinology of Reproduction. J. Velardo, ed. Oxford University Press, New York, pp. 59-97.

Steyn-Parvé, E., and H. Beinert 1958 On the mechanism of dehydrogenation of fatty acyl derivatives of coenzyme A. J. Biol. Chem., 233: 843-852.

Stieve, H. 1923 Untersuchungen über die Wechselbeziehungen zwischen Gesamtkörper and Keimdrüsen. II. Beobachtungen und Versuche an männlicken Hausmäusen und an männlicken Feldmäusen, zugleich ein weiterer Beitrag zur Zwischenzellenfrage. Archiv. Mikr. Anat. Entwick., 99: 390-570.

Talalay, P. 1960 Enzymatic analysis of steroid hormones, Meth. Biochem. Analysis, $8: 119-144$.

Wachstein, M., and E. Meisel 1957 Histochemistry of hepatic phosphatases at a physiologic pH. Am. J. Clin. Path., 27: 13-23.

Wachstein, M., E. Meisel and A. Niedzwiedz 1960 Histochemical demonstration of mitochondrial adenosine triphosphatase with the lead-adenosine triphosphate technique. J. Histochem. Cytochem., 8: 387-388. 
PLATE 1

EXPLANATION OF FIGURES

Processing and printing of all photographs was identical.

All figures with the exception of figures 9 and 10 show the distribution of enzyme activity with nitro blue tetrazolium as the electron acceptor. Sections for the first eight figures were incubated at $37^{\circ} \mathrm{C}$.

1 DPN-diaphorase activity in the fifteen and one-half day fetal murine testis. Ten $\mu$, fixed in acetone at $2^{\circ} \mathrm{C}$, eight minutes incubation. $\times 100$.

2 DPN-diaphorase activity in the Leydig cells of the 20-day postpartum testis. Strong activity is apparent in the few interstitial cells that are found. Six $\mu$, fixed in acetone at $-65^{\circ} \mathrm{C}$, eight minutes incubation. $\times 100$.

3 DPN-diaphorase activity in the murine testis at 30 days postpartum. Six $\mu$, fixed in calcium-formol at $4^{\circ} \mathrm{C}$, eight minutes incubation. $\times 100$.

4 Lactic dehydrogenase activity in the fetal testis at sixteen and onehalf days. Responses are strong and widely distributed. Six $\mu$, fixed in acetone at $-65^{\circ} \mathrm{C}, 30$ minutes incubation. $\times 450$.

$53 \beta$-hydroxysteroid dehydrogenase activity in the embryonic Leydig cells at sixteen and one-half days. Six $\mu$, fixed in acetone at $2^{\circ} \mathrm{C}$, 40 minutes incubation. $\times 450$.

$63 \beta$-hydroxysteroid dehydrogenase activity on day 20 of extrauterine development. Certain Leydig cells within the group show strong activity. Eight $\mu$, fixed in acetone at $2^{\circ} \mathrm{C}, 40$ minutes incubation. $\times 1,000$.

$73 \beta$-hydroxysteroid dehydrogenase activity in the Leydig cells of the adult murine testis. Gradations of response are evident in the moderately reactive cells. Six $\mu$, fixed in acetone at $2^{\circ} \mathrm{C}, 40$ minutes incubation. $\times 1,000$.

8 TPN-diaphorase activity in the embryonic Leydig cells at nineteen and one-half days. The enzyme shows a broad distribution. Six $\mu$, fixed in acetone at $2^{\circ} \mathrm{C}, 30$ minutes incubation. $\times 100$.

9 Nonspecific esterase activity in the postpubertal 30-day testis. Interstitial areas show weak activity. Fast Red ITR, fixed in calciumformol at $4^{\circ} \mathrm{C}$, six minutes incubation at $23-25^{\circ} \mathrm{C}$. $\times 100$.

10 Nonspecific esterase activity in the adult testis. Fast Red ITR, $6 \mu$, fixed in calcium-formol at $4^{\circ} \mathrm{C}$, four minutes incubation at $23-25^{\circ} \mathrm{C}$. $\times 100$. 

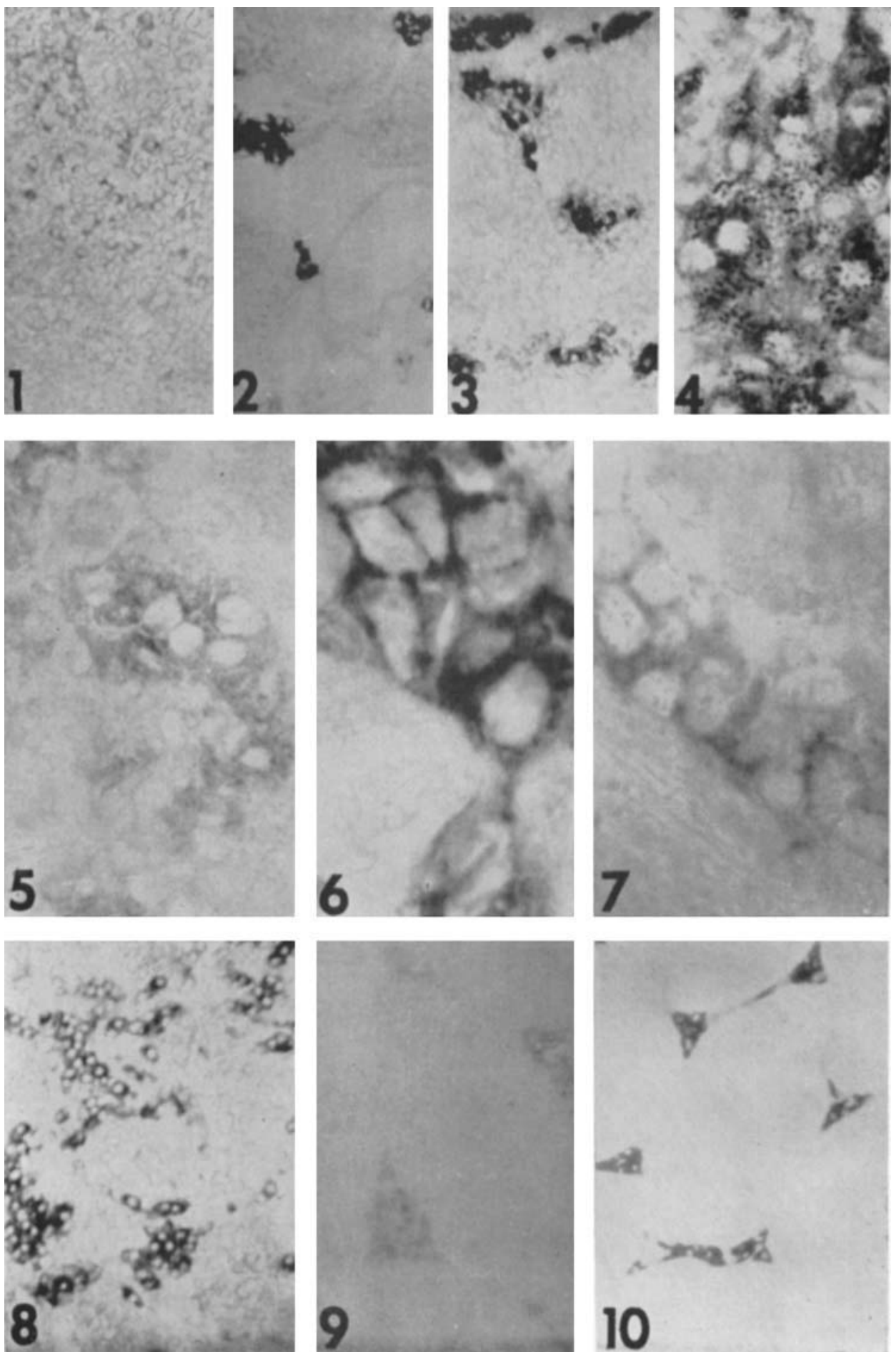